\title{
Silicon Effects on Resistance of St. Augustinegrass to Southern Chinch Bugs and Plant Disease ${ }^{1}$
}

\author{
Alan L. Wright, Ron Cherry, Huangjun Lu, and Pamela Roberts ${ }^{2}$
}

\section{Introduction}

St. Augustinegrass, Stenotaphrum secundatum (Walt.) Kuntze, is used for lawns throughout the southern United States because it can adapt to varying environmental conditions. The southern chinch bug, Blissus insularis Barber, is the plant's most damaging insect pest. Before the release of resistant Floratam St. Augustinegrass in 1973, control of southern chinch bug was primarily through insecticidal applications. Host plant resistance in Floratam lasted until 1985 when southern chinch bug damage on Floratam was reported in Florida (Busey and Center 1987) and later confirmed by Cherry and Nagata (1997).

Silicon ( $\mathrm{Si}$ ) is the second most common element on earth, but it is not considered an essential element for plant growth. However, a growing body of evidence has shown that $\mathrm{Si}$ can enhance plant resistance to insect pests. The solid silica associated with plant cell walls may constitute a mechanical barrier that can block insect mandibles from penetrating into plants. Applied Si and higher available soil Si have improved the resistance of rice to several economically important rice insect pests (Savant, Snyder, and Datnoff 1997). Also, Saigusa et al. (1999) reported reduced insect feeding in turf treated with calcium silicate. However, the insect-plant-silicon response is complex and not always predictable; some studies have shown that insects had no response to silicon (Korndörfer, Cherry, and Nagata 2004).
Similarly, silicon was shown to suppress a range of diseases caused by fungi and fungal-like organisms on several turfgrass species (Datnoff and Rutherford 2004). The silicon enhances physical resistance of the plant cell by depositing in the cuticle or epidermal cells, which may impede penetration by the pathogen (Datnoff, Snyder, and Korndörfer 2001). Gray leaf spot, caused by the fungal pathogen Magnaporthe grisea, occurs on St. Augustinegrass in Florida where warm temperatures and wet weather favor the disease. Previous studies indicated that silicon was effective in reducing damage from this disease on certain varieties of St. Augustinegrass (Datnoff and Nagata 1999; Brecht et al. 2004).

Our study attempted to determine if silicon applications to St. Augustinegrass varieties increase the silicon in the plants and how this increased silicon affects development and survival of southern chinch bugs as well as development of plant diseases. We used three grass varieties in our tests, Captiva, Floratam, and Raleigh. These varieties are in commercial production in Florida and range in resistance to southern chinch bugs. Captiva is resistant, while Floratam was resistant but is now susceptible, and Raleigh is susceptible.

1. This document is SL387, one of a series of the Department of Soil and Water Science, UF/IFAS Extension. Original publication date: September 2013. Visit the EDIS website at http://edis.ifas.ufl.edu.

2. Alan L. Wright, associate professor, Department of Soil and Water Science, Everglades Research and Education Center, Belle Glade, FL; Ron Cherry, professor, Department of Entomology and Nematology, Everglades Research and Education Center, Belle Glade, FL; Huangjun Lu, assistant professor, Horticulture Department, Everglades Research and Education Center, Belle Glade, FL; and Pamela Roberts, professor, Plant Pathology Department, Southwest Florida Research and Education Center, Immokalee, FL; UF/IFAS Extension, Gainesville, FL 32611. 


\section{Results and Discussion}

Silicate slag addition significantly increased the Si content of leaf tissue for all varieties (Table 1). However, varieties differed significantly in their ability to accumulate the applied $\mathrm{Si}$ in tissues. Raleigh had almost twice the $\mathrm{Si}$ content as Floratam and approximately $1 / 3$ more than Captiva. Similar trends among varieties were observed for treatments not receiving slag, indicating that some varieties such as Raleigh have an inherent mechanism for taking up Si from soil and storing it in their tissues better than other varieties such as Floratam.

Phosphorus $(\mathrm{P})$ concentrations in tissue did not vary among varieties. However, phosphorus content in tissue was significantly affected by Si content for two varieties. The addition of slag and accumulation of $\mathrm{Si}$ in tissue caused Floratam and Captiva to have a significantly decreased tissue $\mathrm{P}$ content by an average of $26 \%$. Overall, tissue Si was significantly negatively correlated $(r=-0.46)$ with tissue $\mathrm{P}$. This result may indicate that $\mathrm{Si}$ fertilization may lower the $\mathrm{P}$ requirement of these varieties. In light of potential $\mathrm{P}$ losses as leachate or runoff from over-fertilized fields and lawns, this finding may indicate a potential for decreasing $\mathrm{P}$ fertilization rates for St. Augustinegrass. Additional research may be warranted to directly determine links between Si and P dynamics in turf.

Nitrogen $(\mathrm{N})$ tissue concentrations were not affected by adding slag. With added slag, Raleigh had higher tissue $\mathrm{N}$ than other varieties. Tissue $\mathrm{N}$ was significantly correlated with tissue $\mathrm{P}$, potassium $(\mathrm{K})$, magnesium $(\mathrm{Mg})$, and manganese (Mn). Similar to N, Raleigh receiving silicate slag had higher tissue $\mathrm{K}$ than other varieties that received slag, and tissue $\mathrm{K}$ was significantly increased (20\%) for Raleigh by slag addition. However, Si addition did not increase tissue $\mathrm{K}$ for other varieties.

Tissue calcium (Ca) was generally not influenced by $\mathrm{Si}$ amendment, and few differences among varieties were evident. Adding Si tended to decrease tissue $\mathrm{Mg}$, as $\mathrm{Mg}$ was $23 \%$ higher for treatments not receiving slag. Raleigh also had higher tissue $\mathrm{Mg}$ than all other varieties either with or without slag. Similar to Mg, tissue Mn was generally higher for Raleigh than other varieties, although Si did not influence tissue Mn. Likewise, tissue iron (Fe) was not influenced by $\mathrm{Si}$ addition, and few variety differences were detected. In contrast, $\mathrm{Si}$ addition did significantly influence tissue copper $(\mathrm{Cu})$ for all varieties. Silicate slag addition increased tissue $\mathrm{Cu}$ by an average of $37 \%$. Tissue $\mathrm{Si}$ was significantly correlated with tissue $\mathrm{Cu}(\mathrm{r}=0.85)$. Tissue zinc
(Zn) content was generally not influenced by $\mathrm{Si}$, and there were no variety differences.

Table 2 shows the survival and development of chinch bugs on different varieties and the silicon treatments of those varieties. The two Captiva treatments had a lower mean survival than the other four treatments of Floratam and Raleigh. Captiva both with silicon (33\%) and without silicon $(36 \%)$ had a lower percentage of chinch bug adults of all survivors (nymphs + adults) than the other four treatments (range $=57 \%-74 \%$ ). These latter data indicate that, besides causing direct mortality, Captiva reduced the developmental rate of the chinch bugs during the test. The preceding data are expected because Captiva was the only variety of the three tested currently resistant to southern chinch bugs in Florida (Nagata and Cherry 2003; Trenholm, Cisar, and Unruh 2011).

There were no significant differences in chinch bug survival among silicon treatments in any of the three varieties. The percentage of adults of total live nymphs and adults was similar (range $=12 \%$ ) among silicon treatments in each of the three varieties. These latter data indicate that, besides not causing direct mortality, the silica treatments did little, if anything, to reduce developmental rates of the chinch bugs. As noted earlier, increased Si in plant tissue has been shown to reduce feeding damage in some studies.

However, the insect-plant-silicon response is complex and not always predictable. For example, Peterson, Scriber, and Coors (1988) showed that high levels of silica decreased digestibility in Spodoptera eridania (Cramer) and promoted increased consumption rates. However, larval growth rates were not different from the control even at the highest level of silica ( $20 \%$ dry weight). More recently, Korndörfer, Cherry, and Nagata (2004) found that higher concentrations of silicon in five turfgrass species treated with calcium silicate slag did not affect tropical sod webworm Herpetogramma phaeopteralis Guenee feeding or development. Also, certain plant genotypes are more efficient than others in their accumulation of $\mathrm{Si}$, making them more resistant. Similar to other studies, our study shows that applying elements to plants may affect insects in different and not always predictable ways.

Table 3 shows the results of the disease assessments for the three varieties either amended or not amended with $\mathrm{Si}$. By both rating systems, Raleigh without Si had significantly higher disease incidence and severity compared to all other varieties and Si treatments. Raleigh with Si fertilization had significantly less disease incidence (47\%) than Raleigh without Si (92\%) but was also significantly higher compared 
to Floratam and Captiva, regardless of Si treatment (Table 3). Only Floratam without Si had significantly higher disease incidence compared to the other Floratam and Captiva treatments. Overall, gray leaf spot disease was very low on Captiva, regardless of Si treatment, and on Floratam with $\mathrm{Si}$. These results indicate that overall Raleigh was more susceptible to gray leaf spot; however, adding Si resulted in a significant disease reduction for this variety. Floratam and Captiva had considerably less disease but adding Si assisted in disease suppression on Floratam, as measured by disease incidence, but not severity.

This trial was very successful for disease evaluation of the targeted pathogen. The disease severity in this trial was very high, and differences between the cultivars and application or no application of silicon were readily apparent. It would be useful to examine seasonal effects on this and other diseases over time to see if silicon helps under different environmental conditions and disease pressure.

Table 4 includes the results of morphological measurements of the three St. Augustinegrass varieties with or without silicate slag application to the potting soil. During six weeks, lengths of the longest stolons on average increased by $25.6 \mathrm{~cm}$ in Floratam, $27.4 \mathrm{~cm}$ in Captiva, and $12.5 \mathrm{~cm}$ in Raleigh. All plants of Floratam and Captiva were healthy but the Raleigh plants had gray leaf spot disease (Table 3), which may explain why the Raleigh plants grew poorly and slowly.

Addition of silicate slag significantly increased the length of the longest stolons in Floratam. However, there were no effects on growth of the longest stolons of Captiva or Raleigh, suggesting that varieties responded differently to Si addition to soil. Similarly, Si fertilization significantly promoted formation of new stolons for Floratam and Captiva. Floratam plants grown in Si slag-added soil had 1.5 more stolons than the plants in unamended soil, and Captiva plants in Si slag-added soil produced 3.5 more stolons than the plants in unamended soil. Si fertilization did not significantly affect the number of stolons in Raleigh. There were no significant differences in internode lengths between plants grown in Si-added soil and unamended soil for all three varieties. Among the three leaf characteristics (leaf blade length, width, and sheath length), Si fertilization resulted in increase of leaf blade width in Captiva and Raleigh, but did not significantly influence leaf blade length or sheath length in any of the varieties.

\section{Summary}

The present study showed that growth characteristics in St. Augustinegrass responded differently to Si fertilization. Si treatment had significantly positive effects on three of the six traits in one or two varieties. However, no trait was significantly influenced by Si slag in all three varieties. There were no significant effects of Si fertilization on leaf length, sheath length, and internode length in any of the three varieties. Also, varieties varied in their responses to $\mathrm{Si}$ treatment. Floratam responded to Si fertilization for stolon length and stolon number per plant. Captiva responded for stolon number and leaf blade width, and Raleigh responded for leaf width. Last, all the effects of Si fertilization detected in this study were positive on the growth characteristics.

\section{References}

Brecht, M. O., L. E. Datnoff, T. A. Kucharek, and R. T. Nagata. 2004. "Influence of Silicon and Chlorothalonil on the Suppression of Gray Leaf Spot and Increase Plant Growth in St. Augustinegrass." Plant Dis. 88: 338-344.

Busey, P., and B. Center. 1987. "Southern Chinch Bug (Hemiptera: Heteroptera: Lygaeidae) Overcomes Resistance in St. Augustinegrass." J. Econ. Entomol. 80: 608-611.

Cherry, R., and R. Nagata. 1997. "Ovipositional Preference and Survival of Southern Chinch Bugs (Blissus insularis Barber) on Different Grasses." Int. Turfgrass Soc. Res. J. 8: 981-986.

Datnoff, L. E., and R. T. Nagata. 1999. "Influence of Silicon on Gray Leaf Spot Development in St. Augustinegrass." Phytopath. 89: S19.

Datnoff, L. E., and B. A. Rutherford. 2004. "Effects of Silicon on Leaf Spot and Melting Out in Bermudagrass." Golf Course Manage. 5: 89-92.

Datnoff, L. E., G. H. Snyder, and G. H. Korndörfer (eds). 2001. Silicon in Agriculture. Netherlands: Elsevier Science.

Korndörfer, A., R. Cherry, and R. Nagata. 2004. "Effect of Calcium Silicate on Feeding and Development of Tropical Sod Webworms (Lepidoptera: Pyralidae)." Florida Entomol. 87: 393-395.

Nagata, R., and R. Cherry. 2003. "A New Source of Southern Chinch Bug (Hemiptera: Lygaeidae) Resistance in a Diploid Selection of St. Augustinegrass." J. Entomol. Sci. 38: 654-659. 
Peterson, S., J. Scriber, and J. Coors. 1988. "Silica, Cellulose, and Their Interactive Effects on the Feeding Performance of the Southern Armyworm, Spodoptera eridania (Cramer) (Lepidoptera: Noctuidae)." J. Kansas Entomol. Soc. 61:

169-177.

Saigusa, M., K. Onozawa, H. Watanabe, and K. Shibuya. 1999. "Effects of Porous Hydrate Calcium Silicate on the Wear Resistance, Insect Resistance and Disease Tolerance of Turf Grass 'Miyako."' Grassland Sci. 45: 416-420.

Savant, N. K., G. H. Snyder and L. E. Datnoff. 1997. "Silicon Management and Sustainable Rice Production." Ad. Agron. 58: 151-199.

Trenholm, L., J. Cisar, and J. Unruh. 2011. St. Augustinegrass for Florida Lawns. ENH5. Gainesville: University of Florida Institute of Food and Agricultural Sciences. http:// edis.ifas.ufl.edu/lh010. 
Table 1. Leaf tissue analysis for three St. Augustinegrass varieties*

\begin{tabular}{|c|c|c|c|c|c|c|c|c|c|c|c|}
\hline Variety & $\begin{array}{l}\text { Si } \\
\text { fertilization }\end{array}$ & $\begin{array}{l}\mathrm{Si} \\
\mathrm{g} / \mathrm{kg}\end{array}$ & $\begin{array}{l}P \\
g / k g\end{array}$ & $\begin{array}{l}\mathrm{N} \\
\mathrm{g} / \mathrm{kg}\end{array}$ & $\begin{array}{l}\mathrm{K} \\
\mathrm{g} / \mathrm{kg}\end{array}$ & $\begin{array}{l}\mathrm{Ca} \\
\mathrm{g} / \mathrm{kg}\end{array}$ & $\begin{array}{l}\mathrm{Mg} \\
\mathrm{g} / \mathrm{kg}\end{array}$ & $\begin{array}{l}\mathrm{Mn} \\
\mathrm{mg} / \mathrm{kg}\end{array}$ & $\begin{array}{l}\mathrm{Fe} \\
\mathrm{mg} / \mathrm{kg}\end{array}$ & $\begin{array}{l}\mathrm{Cu} \\
\mathrm{mg} / \mathrm{kg}\end{array}$ & $\begin{array}{l}\mathrm{Zn} \\
\mathrm{mg} / \mathrm{kg}\end{array}$ \\
\hline Captiva & - & $1.8 \mathrm{C}$ & $4.6 \mathrm{a}$ & $26.7 \mathrm{ab}$ & $23.8 \mathrm{~b}$ & $3.0 \mathrm{a}$ & $1.5 \mathrm{~b}$ & $225 a$ & $37 b$ & $27 b c$ & $162 b$ \\
\hline Floratam & - & $1.0 \mathrm{c}$ & $3.9 a b$ & $25.0 \mathrm{abc}$ & $20.6 b c$ & $2.1 \mathrm{~b}$ & $1.5 \mathrm{~b}$ & $194 a b$ & $55 a b$ & $21 c$ & $280 a$ \\
\hline Floratam & + & $5.3 \mathrm{~b}$ & $3.0 \mathrm{c}$ & $21.9 b c$ & $17.0 \mathrm{c}$ & $2.1 \mathrm{~b}$ & $1.0 \mathrm{c}$ & $150 \mathrm{~b}$ & $64 \mathrm{a}$ & $42 a b$ & $154 b$ \\
\hline Raleigh & + & $10.4 \mathrm{a}$ & $3.9 \mathrm{abc}$ & $29.5 \mathrm{a}$ & $28.6 \mathrm{a}$ & $2.7 a b$ & $1.7 \mathrm{ab}$ & $230 a$ & $48 a b$ & $59 a$ & $151 \mathrm{~b}$ \\
\hline
\end{tabular}

${ }^{*}$ Means in the column followed by the same letter are not significantly different (alpha $\left.=0.05\right)$ using a Least Significant Difference test.

Table 2. Survival* and development of southern chinch bugs held 21 days on different varieties with different silicon treatments

\begin{tabular}{|c|c|c|c|}
\hline \multirow[b]{2}{*}{ Variety } & \multicolumn{2}{|c|}{ Survival } & \multirow{2}{*}{$\begin{array}{l}\% \text { adults of } \\
\text { total survivors }\end{array}$} \\
\hline & $0 \pm S D$ & Range & \\
\hline Captiva - Si & $2.2 \pm 2.3 \mathrm{~B}$ & $0-6$ & 36 \\
\hline Captiva + Si & $1.8 \pm 1.8 \mathrm{~B}$ & $0-4$ & 33 \\
\hline Floratam - Si & $5.2 \pm 1.9 \mathrm{~A}$ & $3-8$ & 57 \\
\hline Floratam + Si & $3.6 \pm 2.1 \mathrm{AB}$ & $2-7$ & 67 \\
\hline Raleigh - Si & $4.2 \pm 1.5 \mathrm{AB}$ & $2-6$ & 66 \\
\hline Raleigh + Si & $6.0 \pm 3.2 \mathrm{~A}$ & $2-9$ & 74 \\
\hline
\end{tabular}

Table 3. Disease incidence and severity ratings for gray leaf spot on three varieties of St. Augustinegrass

\begin{tabular}{|c|c|c|c|}
\hline \multirow[b]{2}{*}{ Variety } & \multirow[b]{2}{*}{ Si fertilization } & \multicolumn{2}{|c|}{ Disease ratings ${ }^{*}$} \\
\hline & & $\begin{array}{c}\text { Disease incidence } \\
\text { (\% of affected leaflet/runner) }\end{array}$ & Disease severity (\% affected foliage) \\
\hline Captiva & - & $6.0 \mathrm{~d}$ & $1.11 \mathrm{c}$ \\
\hline Captiva & + & $7.0 \mathrm{~d}$ & $0.4 \mathrm{c}$ \\
\hline Floratam & - & $26.0 \mathrm{c}$ & $2.6 \mathrm{c}$ \\
\hline Floratam & + & $9.0 \mathrm{~d}$ & $0.75 \mathrm{c}$ \\
\hline Raleigh & - & $92.0 \mathrm{a}$ & $43.0 \mathrm{a}$ \\
\hline Raleigh & + & $47.0 \mathrm{~b}$ & $17.4 \mathrm{~b}$ \\
\hline
\end{tabular}

Table 4. Growth characteristics* of three St. Augustinegrass varieties with (+) and without (-) silicon fertilization

\begin{tabular}{|c|c|c|c|c|c|c|c|}
\hline Variety & Si fertilization & $\begin{array}{l}\text { Stolon growth } \\
(\mathrm{cm})\end{array}$ & $\begin{array}{l}\text { Number of } \\
\text { stolons }\end{array}$ & $\begin{array}{l}\text { Leaf blade } \\
\text { length }(\mathrm{cm})\end{array}$ & $\begin{array}{l}\text { Leaf blade } \\
\text { width }(\mathrm{cm})\end{array}$ & $\begin{array}{l}\text { Sheath length } \\
(\mathrm{cm})\end{array}$ & $\begin{array}{l}\text { Internode } \\
\text { length }(\mathrm{cm})\end{array}$ \\
\hline Captiva & - & $27.4 \mathrm{ab}$ & $7.6 \mathrm{~b}$ & $1.8 \mathrm{~d}$ & $0.5 \mathrm{~d}$ & $1.7 \mathrm{~b}$ & $3.2 \mathrm{~b}$ \\
\hline Captiva & + & $27.8 \mathrm{ab}$ & $11.1 \mathrm{a}$ & $2.0 \mathrm{~cd}$ & $0.6 \mathrm{c}$ & $1.6 \mathrm{~b}$ & $3.5 \mathrm{~b}$ \\
\hline Floratam & - & $25.6 \mathrm{~b}$ & $4.4 \mathrm{c}$ & $3.0 \mathrm{ab}$ & $0.9 a$ & $2.4 \mathrm{a}$ & $4.4 \mathrm{a}$ \\
\hline Floratam & + & $32.1 \mathrm{a}$ & $6.1 \mathrm{~b}$ & $3.2 \mathrm{a}$ & $0.9 \mathrm{a}$ & $2.5 \mathrm{a}$ & $4.5 \mathrm{a}$ \\
\hline Raleigh & - & $12.5 \mathrm{c}$ & $1.5 \mathrm{~d}$ & $2.3 \mathrm{~cd}$ & $0.6 \mathrm{c}$ & $1.6 \mathrm{~b}$ & $2.9 \mathrm{~b}$ \\
\hline Raleigh & + & $12.4 \mathrm{c}$ & $2.0 \mathrm{~d}$ & $2.5 \mathrm{bc}$ & $0.7 \mathrm{~b}$ & $1.8 \mathrm{~b}$ & $3.3 \mathrm{~b}$ \\
\hline
\end{tabular}

